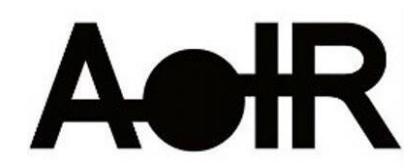

Selected Papers of \#AoIR2021: The 22nd Annual Conference of the

Association of Internet Researchers

Virtual Event / 13-16 Oct 2021

\title{
\#YELLOWPERILSUPPORTSBLACKPOWER: MEMORY WORK FOR INTERRACIAL SOLIDARITY
}

\author{
Yena Kang \\ University of Massachusetts Amherst

\section{Introduction}

After George Floyd's murder in May 2020, Monyee Chau posted on her Instagram page some artwork with the slogan, \#YellowPerilSupportsBlackPower (Figure 1). The artwork, which included symbols representing Asians and African Americans, ignited Asians' activism in support of African Americans and was circulated on multiple social media platforms. In this study, I view the \#YellowPerilSupportsBlackPower movement (YPSBP) as digital activism, and I analyze how Asian Americans project their "Asianness" to advocate for the Black community. In particular, I focus on how memory work plays a key role in a process by which Asian Americans produce affective ties with the Black community to build a multiracial identity extending beyond color lines.

\section{Contextualizing Memory Work}

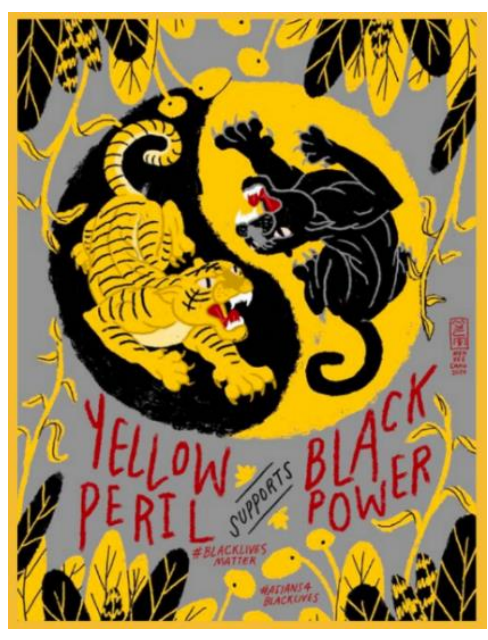

Figure 1. Monyee Chau's work posted on Instagram

José van Dijck (2007) defined mediated memories as "the activities and objects we produce and appropriate by mediated technologies, for creating and re-creating a sense of past, present, and future of ourselves in relation to others" (p. 21). Expanding the concept of memory work into the contemporary context of social media, Humphreys (2020) considers memory work to be one of the media accounting practices that involve the creation, circulation, and consumption of media traces (e.g., writing a text, taking a photo). According to Humphreys, remembrancing — the term she uses instead of memory work - creates a media trace that may involve performing identities that invite reflexivity.

In this paper, I consider memory work as practice, particularly focusing on how memory work plays a key role in building interracial solidarity activism of the Asian community in digital spaces.

Suggested Citation (APA): Kang, Yena. (2021, October). \#YellowPerilSupportsBlackPower: Memory Work for Interracial Solidarity. Paper presented at AolR 2021: The 22nd Annual Conference of the Association of Internet Researchers. Virtual Event: AolR. Retrieved from http://spir.aoir.org. 


\section{Methods}

This study views the Asian American \#YellowPerilSupportsBlackPower, a hashtag activism as a field site (Bonilla \& Rosa, 2015) to analyze how interracial solidarity has been organized by marginalized groups, particularly racialized ones in digital counterpublics. I focused on three hashtags that utilize an Asian identity to show support for Black people: \#yellowperilssupportblackpower, \#Asiansforblacklivesmatter and \#Asians4blacklives. I selected 60 Instagram posts from among the top posts for each of these three hashtags (total of 180 posts) from June 5th, 2020 to December 31st, 2020. Using a grounded theory approach (Charmaz, 2014) to reading all text and images in the corpus, I identified three thematic types of memory work. I also paid attention to how participants ${ }^{1}$ used platform vernacular (Gibbs et al., 2015) to perform memory work while engaging in YPSBP activism.

\section{Reckoning Racial Suffering in Childhood}

Participants confess that their wounding experiences stem from their racial identity. The revelation of their racial and diasporic identity shapes their experiences of racism. They compare their racist treatment as Asians with the oppression suffered by Blacks. Many participants share "I can feel your pain" narratives because they, as racial minorities, are always subject to racism. In terms of vernacular practice, selfies play a role in showing racial identity by allowing participants to reminisce about their racialized experiences. Childhood photos are another noticeable visual image type. Images of the younger self complement autobiographical reflections of self, family, and friends as members of a racial minority.

\section{Reactivating Historical Moments and Figures}

This memory work reactivates history by invoking historical figures and articulating historical justice movements in terms of YPSBP activism. A frequently mentioned figure is Japanese American Yuri Kochiyama, a grassroots organizer and activist of the civil

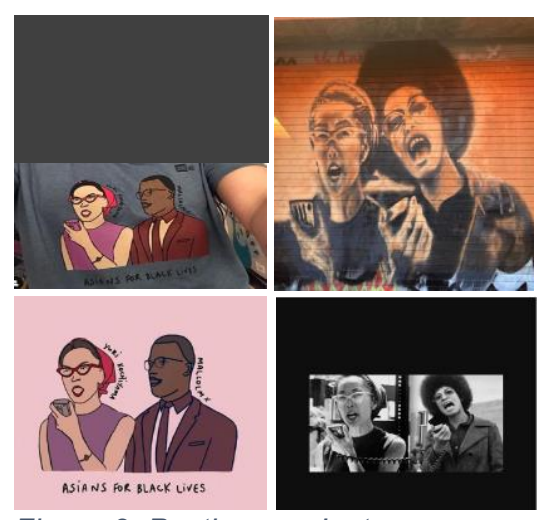

Figure 2. Postings on Instagram rights era. She is best known for her political involvement with Malcolm X, African American leader and human rights activist. Because most supporters of Malcolm X were young Blacks, the friendship between Malcolm $X$ and Yuri Kochiyama was considered unique. Additionally, Kochiyama is historically connected to Angela Davis, a well-known African American activist. Both were human rights activists of the same age. Participants in YPSBP recall these female activists as "two monumental women in the civil rights movement who embody \#YellowPerilSupportsBlackPower." Using the remix practice and artistry work (e.g., memes), historical figures

\footnotetext{
${ }^{1}$ I use the term participant instead of Instagram "user" because I consider those who engage in cultural production by posting text and visual images with the hashtag \#YellowPerilSupportsBlackPower to be "participating" in digital activism in the context of racial and identity politics.
} 
are symbolized, circulated, and juxtaposed with other figures as well as contextualized within the current moments of YPSBP activism (Figure 2).

\section{Confessing Past Indifference, Unlearning Internalized Bias, and Learning Solidarity}

Participants performing this type of memory work confess how ignorant and indifferent Asians have been toward the suffering of African Americans. Comparing the microaggressions toward Asians with the life-threatening brutality African Americans suffer, participants argue that Asians should no longer be complacent and silent about racism toward African Americans. Participants confess they have been indifferent to the model minority myth generated by White supremacy. As part of an action to debunk this myth, participants post infographic guides pointing out negative implications of the myth and how White supremacy ideology operates.

\section{Conclusion}

This study demonstrates that memory work plays a key role in legitimatizing a process through which Asian Americans produce affective ties with the Black community. By narrating their individual and collective memory work, which includes racialized experiences and histories, the Asian American community is arousing emotions such as shame, anger, and rage, emotions that become connected to the suffering and oppression that the Black community faces. The formation of a memory mechanism reflects remembrance as a form of resistance (Yang \& Wu, 2018) and emotional achievement (Yang, 2000).

In the history of the United States, Asian communities have been caught in an ambivalent position between the Black and White color line (Wu, 2003). Memory work enables the Asian community to legitimize the formation of a multiracial identity with the Black community and with multiracial rights movements beyond the boundary of color. In this study, I advance our understanding of digital activism for racial rights by illustrating how memory work is manifested in the context of Web 2.0 participatory culture.

\section{References}

Bonilla, Y., \& Rosa, J. (2015). \# Ferguson: Digital protest, hashtag ethnography, and the racial politics of social media in the United States. American ethnologist, 42(1), 4-17.

Charmaz, K. (2014). Constructing grounded theory. sage.

Gibbs, M., Meese, J., Arnold, M., Nansen, B., \& Carter, M. (2015). \# Funeral and Instagram: death, social media, and platform vernacular. Information, Communication \& Society, 18(3), 255-268.

Humphreys, L. (2018). The qualified self: Social media and the accounting of everyday life. MIT press. 
Van Dijck, J. (2007). Mediated memories in the digital age. Stanford University Press.

Wu, F. H. (2003). Yellow: Race in America beyond black and white. BasicBooks.

Yang, G. (2000). Achieving emotions in collective action: Emotional processes and movement mobilization in the 1989 Chinese student movement. The Sociological Quarterly, 41(4), 593-614.

Yang, G., \& Wu, S. (2018). Remembering disappeared websites in China: Passion, community, and youth. new media \& society, 20(6), 2107-2124. 